ated with degrees in politics, philosophy, and economics. More crucially, it came from encounters with the brutal realities of the communist takeover of Bulgaria at the end of the war and beginning of the peace, when he was a member of the British Foreign Office after having served in the infantry. After the Bulgarian experience, he returned to London to work in the Foreign Office's Information Research Department, where he honed his skills as a Soviet analyst until he entered academia in 1956.

The list of his seminal works certainly starts with Power and Policy in the U.S.S.R.: The Study of Soviet Dynastics (St. Martin's Press, 1961), one of the first systematic attempts to think about Soviet politics in the context of the struggle for succession behind the Kremlin dictatorship. In this book, Conquest was among the first (and best) practitioners of the art of historical Kremlinology. Long before documents on the period were published, Conquest was able to discern the character of the political struggle over Iosif Stalin's mantle, which resulted in the trial and execution of Lavrentii Beriia and the ascendancy of Nikita Khrushchev.

The most widely acclaimed of his works was the remarkable The Great Terror: Stalin's Purge of the Thirties, initially published by Macmillan in 1968 and then reissued by Oxford University Press as The Great Terror: A Reassessment in 1990 and 1998. This classic of Soviet history was the first and is still the best account of the fearsome Stalinist repressions, trials, killings, and torture of the 1930s that permanently disfigured Soviet society, politics, and culture. It was widely read in dissident circles and later serialized in Neva during glasnost, when Conquest made frequent visits to the Soviet Union. We call the period the Great Terror because of his work.

Conquest's study of the Ukrainian terror-famine (Holodomor) of 1932-33, The Harvest of Sorrow: Soviet Collectivization and the Terror-Famine (Oxford, 1986), continues to exert a profound influence on Soviet and Ukrainian history and historiography. In this work, Conquest created another masterpiece of modern historical writing by carefully reconstructing the story of the Ukrainian tragedy from émigré memoirs, scattered articles in the Soviet press, and accounts of foreign diplomats and visitors.

Russian and east European studies owes a huge debt to Robert Conquest for pioneering avenues of research that others were hesitant to tread. But more than that, he was able to write about the Soviet experience-especially the Stalinist period-in splendid prose that both engaged his readers and taught them about a world that initially seemed distant and alien. He will be dearly missed.

JOHN B. DUNLOP

Hoover Institution

NORMAN M. NAIMARK

Stanford University

August 2015

\title{
Ekaterina Iur'evna Genieva, 1946-2015
}

Ekaterina Iur'evna Genieva died on July 9, 2015, after a long and courageous battle with cancer. Her many friends worldwide called her Katia, and that is how I shall remember her, simply as Katia, my friend and colleague.

The Foreign Literature Library in Moscow, founded in 1923 by Margarita Ivanovna Rudomino, served the Soviet state in both protecting and controlling foreign literature. The library was a wonderful workplace for students of foreign literatures and languages, a legitimate Soviet institution where they could conduct research on oftenforbidden subjects, and a destination for students, scholars, and the general public 
who wanted to learn about the world through reading its literatures. Katia began her career there as a researcher of British literature. She had begun publishing on James Joyce while a student at Moscow State University, and she defended her dissertationthe first in the Soviet Union on Joyce-in 1972. She remained an active scholar all her life and made important contributions to Joyce studies as well as to the literature of librarianship broadly defined.

When I first met her, in the summer of 1990 during the Fourth World Congress of Soviet and East European Studies, held in Harrogate, England, Katia had just been elected deputy director of the library, serving under the prominent philologist Viacheslav Ivanov. Three years later, in 1993, she was named director general, a post she held until her death. From that time forward, she led the Foreign Literature Library and its excellent staff to its current position as arguably the most progressive and outward-looking cultural institution in the former Soviet Union. The library is dotted with cultural centers established by various foreign countries, each offering publications in their respective languages and attractive reading rooms in which Russians can learn about other cultures. And Katia's efforts at bringing the world to Russia and Russia to the world did not go unnoticed outside the country. Governments, cultural institutions, and universities from Tokyo to London gave her awards and honorary degrees.

Considered singly, Katia's accomplishments in the tumultuous first quarter century of post-Soviet Russia are amazing; taken together, they are overwhelming. She was a woman of enormous energy, determination, and vision. She believed strongly that libraries can and should play a vital role in making information and knowledge accessible to everyone who needs and wants it, regardless of age, status, citizenship, and other limiting factors. By coincidence, on the first day of the attempted coup in August 1991, she signed an agreement with the BBC to place a standing exhibit in the library so Russians could hear and see the news from Britain. She also allowed the library's photocopier to be used to "publish" the wall newspapers people relied on during the coup. (An official passing by saw what they were doing through the window; he came in and advised drawing the curtains.) When libraries shut their spetskhrany, those special closed collections of banned publications, Katia transformed the space where the Foreign Literature Library's spetskhran had been into a reading room for children and invited families to bring their kids to the library, creating special events for them.

The Foreign Literature Library has reported to the Ministry of Culture since Soviet times, and Katia was able to build on an existing network of public research library directors throughout Russia's regions and the former Soviet Union with whom she shared and promoted her ideas. She didn't believe in one-way streets, and she was eager to learn from colleagues worldwide. As soon as the borders opened, Katia began traveling extensively, and everywhere she went, she observed with keen interest how libraries and other cultural institutions functioned in their own societies. I was with her once in a public library in Illinois where a book sale was in progress. "What's going on here?" she asked. When I explained about such sales, her eyes lit up. "We'll do it in Moscow," she said, "and I'll tell everyone about it." She did, and soon book sales sprouted up in Russian libraries.

One of her major concerns immediately after the end of the Soviet Union was the paucity of foreign publications in the country. She took the lead in Book Aid, a project that started with British publishers and other organizations sending more than a million books to Moscow. Other countries followed suit, and more millions of books began arriving from the United States and Europe. At the library, Katia and her staff stored and organized the books and arranged distribution to libraries throughout the country, a tremendous feat given the lack of infrastructure in the country at the time. 
There were certain books in the former Soviet Union and eastern Europe that aroused Katia's deep concern: "trophy" books from the warzones of Europe. Crammed into decommissioned churches and shelved in library book stacks, many in extremely poor condition, these unacknowledged collections, including everything from cookbooks to Gutenberg Bibles, had been hidden, ignored, and forgotten. Katia took the trophy books up as one of her causes and worked with partners in Germany and other countries to identify collections, make information available to everyone, and, when possible, return books to their rightful owners. A further project was bringing to Russia publications by émigré writers who had left the country during the Soviet era and whose books had been banned. For instance, she worked with the YMCA Press in France, publisher of many notable émigrés, to bring books to libraries around the former Soviet Union-and leave them there.

Another of Katia's causes was tolerance. She mounted dozens of exhibitions on difficult, troubling topics-antisemitism in Russia and the destruction of Jews on Soviet soil during World War II, the wars in Chechnia, censorship-and took them on the road to libraries all over the country, accompanied by books, lectures, and seminars. I once asked her if she was ever afraid of reprisals. "A little," she said, and shrugged. "One must go on."

Finally, I hope historians will record the far-reaching and profound effects of George Soros's generous efforts in Russia, beginning in the chaotic 1990s, in which Katia played a leading role. She was president of one of Soros's largest programs, the Open Society Foundation in Russia, which gave hundreds of millions of dollars for establishing Internet access all over the country and for textbooks for schools and institutes for higher education, health, and tolerance, and, last but not least, libraries and cultural centers. These projects established a pattern of matching funds from national, regional, and local governments and foundations to guarantee sustainability.

Despite her illness, Katia continued to travel internationally and within Russia, working tirelessly on various projects. In her last year, we spoke nearly every day by phone. "Where are you today?" I would ask, and she would name a European country or a city on the other side of Russia, many time zones removed from Moscow. "I arrived this morning, and I'll fly back on Tuesday. Everything's going splendidly. Call again tomorrow."

MARIANNA TAX CHOLDIN

University of Illinois, Urbana-Champaign

September 2015

\section{Andrei Konstantinovich Sokolov, 1941-2015}

Andrei Konstantinovich Sokolov was an accomplished social historian of international stature and the leading historian of the Soviet working class of the prewar period. The most productive member of the remarkable cohort of V. Z. Drobizhev's students who became leaders of the late Soviet historical profession, Sokolov established himself as a leading figure in Soviet history and a major influence on those he trained.

Andrei came from the working class he studied. Born into privation during World War II (which killed his father), he spent hard childhood years in small Vladimir region towns like Iur'ev-Pol'skii and Kineshma. From age seventeen, he worked making bread, cutting timber, and stoking fires in various factories. A true vydvizhenets promoted from the proletariat, Andrei was identified by Soviet authorities as a worker with intellectual promise. Selected to attend Moscow State University in 1963, he ex- 